Kinestetik : Jurnal Ilmiah Pendidikan Jasmani 5 (1) (2021)

Kinestetik : Jurnal Ilmiah Pendidikan Jasmani

https://ejournal.unib.ac.id/index.php/kinestetik/index

DOI : 10.33369/jk.v5i1.14251

\title{
PRINCIPAL'S LEADERSHIP IN DEVELOPING THE COMPETENCIES OF PHYSICAL EDUCATION TEACHERS IN MUHAMMADIYAH NITIKAN ELEMENTARY SCHOOL YOGYAKARTA
}

\author{
Arifin $^{1 *}$, Enung Hasanah ${ }^{2}$ \\ ${ }^{12}$ Master of Educational Management, Faculty of Teacher Training and Science, Universitas \\ Ahmad Dahlan, Yogyakarta, Indonesia
}

\section{Article Info}

Article History :

Received : January 2021

Revised : February 2021

Accepted : March 2021

Available online : March 2021

\section{Keywords:}

Competence, Development Physical Education, Principal

\section{Abstract}

This study explores the principal's leadership role in developing Muhammadiyah Nitikan Yogyakarta Elementary School's physical education teacher's competencies. The researchers used a qualitative method in the research. The researchers collected the data through collecting data from observations, interviews, and documentation. The sample is determined through purposive sampling. The number of participants in this study amounted to 10 respondents. The sample consisted of principals, curriculum time, arts and talent lecturers, physical education teachers, and students. This study concluded that the principal had made full efforts by enforcing programs and activities to develop physical education (PE) teachers' competencies at Muhammadiyah Nitikan Yogyakarta Elementary School to teach physical education effectively and master learning materials. Programs enforced to improve the competencies of physical education teachers namely as follows: 1) planning for developing the competence of PE teachers by following the Teacher Work Group (KKG) and the Subject Teacher Deliberation (MGMP); 2) Mapping the competence of teacher skills through competency tests and writing scientific articles or enforcing classroom action research (PTK); 3) Giving opportunities for PE teachers to attend sports training and seminars; 4) Direct coaching by the principal. 


\section{INTRODUCTION}

Physical education teachers are executors of sports education learning at every level of school. Physical education teachers are expected to make modifications in the form of learning innovations and foster students' motivation to have a sense of activity, creative skills and be able to excel in education or noneducation in sports. Teachers' ability to carry out learning innovations is one of the elements forming teacher professionalism which is indispensable in achieving learning objectives. According to (Wardoyo, Cipto\&Herdiani, 2017), teacher professionalism is a teacher's thinking style about their profession, why and how to be professional, behave, and apply their knowledge, knowledge, and skills related to their job.

Sports education is a subject that falls within the elements of the educational level, starting from kindergarten to senior secondary and vocational classes. In the national education system's nomenclature, this education teaches how a teacher can lead and manage students' physical skills. Physical education plays a strategic role in developing students' cognitive, affective and psychomotor abilities because physical education has universal properties that can underlie human development in terms of mental, character, logical and innovative thinking (Muhajir, 2016).

One of the authorities in the management of education policy by regional autonomy is stipulated in (Undang-Undang Republik Indonesia nomor 23 Tahun 2014, 2014), where the law explains that the success of education is not entirely under the authority of local governments to meet regional needs, which include aspects of financing, human resources and infrastructure. Still, it remains the authority of the school. The school's elements include curriculum, learning, evaluation, accreditation, infrastructure, learning methods, and learning budgets. Therefore, the principal's leadership and the teacher's role are needed to be responsible for the quality of the learning process and improve the quality of education quality nationally (Rosyada, 2013).

The success of education must be supported by all elements that support it, both from teachers, students and parents, school committees, or the education office, but the principal's role has a significant influence on actual achievement, which can be seen through student and school achievement. According to (S., Bustan, Herculanus Bahari Sindju \& Suib, 2019) the principal's role as the captain of education in the education unit has a central and strategic point to guide a school that can achieve national education goals and priorities that must be carried out maximally.

All subjects must have the principal's support, not to mention that the Sports Physical Education (PJOK) subject must be the main priority in organizing national education. In the realm of education, sports are part of the subjects that must be in the school schedule. In schools, the term sports subjects are called Sports and Health Education (PJOK). Meanwhile, the teacher calling for him is often called a sports teacher, physical education teacher or PJOK teacher. Sports subjects play a strategic role in developing students' knowledge (cognitive), affective 
(attitude), and psychomotor (movement) abilities because physical education has universal properties that can underlie human development in terms of mental, character, logical and innovative thinking (Muhajir, 2016).

Physical education as a subject for students to develop cognitive, intellectual, attitude and movement or the psychomotor potential to improve physical fitness. To produce effective physical education learning, it takes PJOK teachers who have good competence in the learning system. (Selvi, 2011), states that in general, teacher competence can be seen from nine different dimensions, namely teaching competence in the field, competency in conducting research, competency in curriculum knowledge, competence in life-long learning, cultural and social ethics competence, mental and emotional competence, competence in communication skills, competence in the field of information and communication technology (ICT), and environmental competence.

This is in line with the results of research by (Wardoyo, Cipto\&Herdiani, 2017), which states that based on teachers' perceptions, teacher competence does not only include abilities in terms of knowledge but in various other matters which include 1) relating to values in managing potential learners; 2) understanding of the education system and its contribution to its development; 3) knowledge of subjects, pedagogy and curriculum; and 4) self-evaluation and professional development. In the national education system, teacher competencies are summarized in 4 main competencies: social, professional, pedagogical, and personality competences (Depdiknas, 2005). All of these must be owned by all teachers, including physical education teachers. Therefore, every teacher must develop their competence to become a professional teacher.

In this era, physical education in Indonesia is not in good condition because it is still considered ineffective, so that sports knowledge to students is not maximally accepted. Physical education is currently in a dire state because of the ineffective learning of physical education in schools and poor understanding of the importance of learning physical education that is not socialized early on (Setyawan, 2016). This statement has the value that PJOK teachers are essential in creating superior human resources and bringing a more developed country.

The quality of sports teachers at Muhammadiyah Nitikan Elementary School will impact teacher competencies and teachers' main tasks and functions. Some teachers also have professional competency problems because the use of computers constrains them. With the restrained use of computers, the making of lesson plans and learning media is just a copy-paste with other physical education teachers. Likewise, with pedagogical competence, where there is a lack of enthusiasm for teachers in theory and developing it, even though in the 4.0 era, this competency is a mandatory competency that must be mastered to manage the learning process for students.

The principal of SD Muhammadiyah Nitikan is still passive, and there has been no movement to help physical education teachers improve their competence. Ideally, leaders in 
educational institutions can prepare programs related to teacher development, both in the preparation of learning administration or development in the realm of four teacher competencies that must be fulfilled, namely teaching pedagogic competence, professional teachers, social skills and personalities. In the Muhammadiyah Nitikan Primary School work program, ideally, there is a program for teacher development because to achieve quality education, qualified teachers are needed.

When a teacher wants to be competent and professional physical education teachers, it is necessary to have school leaders who can prepare programs related to teacher development, both in the preparation of learning administration or in developing teacher competencies to achieve educational goals. (Bukit, 2017), explains that a leader is a person who can carry out a management cycle through any event to achieve a goal. This study explores the best practices of principal leadership at Muhammadiyah Nitikan Elemtari School in building physical education teachers' competence.

\section{METHODS}

This research used a qualitative method with the data collection process using interview techniques to participants related to the development of physical education teachers' competency. This data collection process adjusted to the research objective, namely knowing what and how the school principal's policies were to develop the competence of physical education teachers at Muhammadiyah Nitikan Elementary School. The number of participants in this study amounted to 10 respondents. The purposive sampling technique's determination was determined by considering specific criteria (Sugiyono, 2019). The sample consisted of principals, curriculum time, arts and talent lecturers, physical education teachers, and students. The achievements in this research are in the form of activities, documents, or data related to the development of the competence of physical education teachers at SD Muhammadiyah Nitikan

\section{Sampling Procedures.}

Data collection techniques and instruments were written using a) Observation, which later can find out the implementation of the principal process to develop the competence of physical education teachers at Muhammadiyah Nitikan Elementary School Yogyakarta. The author made observations by looking at the principal policies, which were linear with the development of physical education teachers' competence at SD Muhammadiyah Nitikan. b) The use of a structured interview model. In this technique, researchers make structured questions so that data collection will be more objective.

The subjects in question are school principals, curriculum time, arts and talent time lecturers, physical education teachers, and students. c) Documentation, the authors get documents about school data or programs from schools related to the development of physical education teachers' development at SD Muhammadiyah Nitikan. The number of participants in this study amounted to 10 respondents. The purposive sampling 
technique's determination was determined by considering specific criteria (Sugiyono, 2019). The sample consisted of principals, curriculum time, arts and talent lecturers, physical education teachers, and students. The main questions in the interview guide used to explore the data in this article are; 1) How was the process of implementing the PE learning activities at SD Muhamammadiah Nitikan while you were the principal of the school; 2) How is the competency ability of physical education teachers in Muhammadiyah Nitikan Elementary School; 3) How does the principal endeavor to develop the competency abilities of physical education teachers at SD Muhammadiyah Nitikan?

\section{DISCUSSION}

1) Planning for competency development of physical education teachers

Planning is an effort made by the principal to carry out development activities for competency physical education teachers at SD Muhammadiyah Nitikan so that it can run smoothly, effectively, and efficiently and in the future can achieve the goals of this development. In planning the development competency of physical education teachers at SD Muhammadiyah Nitikan by carrying out programs and activities that will improve the quality of physical education teacher competencies, namely by monitoring and coaching through educational training, sports seminars, including teachers in the Teacher Working Group (KKG) in PJOK subjects, Subject Teacher Deliberative Groups (MGMP) or independent education and training in class and non-training. Namely, activities to improve education and training skills such as sports competition among teachers, writing scientific articles, or classroom action research (PTK).

Coaching and development of physical education teachers through training and sports seminars are carried out in the new academic year organized by universities with vocational sports education or the Faculty of Sports Science (FIK). The KKG and MGMP PJOK activities are held in each UPT of the East Jogjakarta region and are carried out every three months. Meanwhile, scientific article writing and Classroom Action research (PTK) is usually carried out to participate in competitions such as PGRI Day or article writing competitions and other competitions.

In developing the competence of PJOK teachers at SD Muhammadiyah Nitikan, the principal does careful planning, paying attention to the potential and context of the school environment so that the results are optimal. This shows that the principal has carried out the quality management function and acts as a driving force, which has an influence on educational organizations, and as an example for educators (Mardhatillah, 2019).

\section{2). Mapping teacher}

Competencies This competency mapping is part of the process of developing the competence of physical education teachers at SD Muhammadiyah Nitikan. According to (Mulyana, 2013) the quality of teachers, of course, must go through the testing phase according to their competencies. Competency testing must be in accordance with regional 
autonomy policies. This competency test aims to determine the ability of teachers in each region. This competency recording activity is useful for the purposes of description and rank, both for the appointment of school principals or school representatives.

The competency test stage is carried out in stages and on a scale because quality teachers will provide education and quality learning as well. The following is a part of the teacher competency test, which has the following benefits: (1) It is a standard development tool for teacher professional competence. (Selvi, 2011) explains, "the teacher competency test is a tool to develop standards for the professional competence of teachers. From the results of the competency, it can be seen that the teacher's ability and aspects that need to be improved and need guidance; (2) the teacher admission selection system, (Mulyana, 2013) explains that "competency testing is one way to select new teacher admissions." In this case, teacher acceptance is strictly based on the competency standards they have. Not based on personal likes and dislikes"; (3) As a teacher competency mapping tool, (Mulyana, 2013) explains, "based on competency tests, teacher competencies can be mapped and made into groups based on their scores. Groups that are deemed insufficient will get attention and guidance in order to improve their competence"; (4) Evaluation materials for curriculum development. (Mulyana, 2013) argues "student involvement and learning models will determine the quality and success of education"; (5) how to supervise and foster teachers, (Mulyana, 2013) argues that "teachers who have good competence will be happy to carry out their duties, think creatively, professionally and make it easier for someone to be accepted as an educator; (6) as evidence of teacher learning. (Mulyana, 2013) explains, "The success of students is not entirely determined by the curriculum and school management but is more determined by the quality of a teacher's competence."

3).Providing opportunities for PJOK teachers to participate in various education and training.

Physical education training is an effort to improve the competencies of teachers.(Bukit, 2017) states that the effort to hold education and training is a form of coaching and refresher so that educators or employees can: (1) Foster a personality spirit to serve more in the workplace, agencies, and society; (2) improving the quality of teaching skills for teachers and being able to work as well as possible according to their main tasks; (3) Acquiring good work skills so as to get good and satisfying results; (4) increase the ability to be able to plan work properly and correctly; (5) Adding insight and experience in the world of work from the knowledge and skills possessed.

The (Kementerian Pendidikan dan Kebudayaan, 2012) explains that the process of increasing competency in teachers can be carried out in ways and strategies; it can be in the form of formal education or a training model, as described in Figure 1 below: 


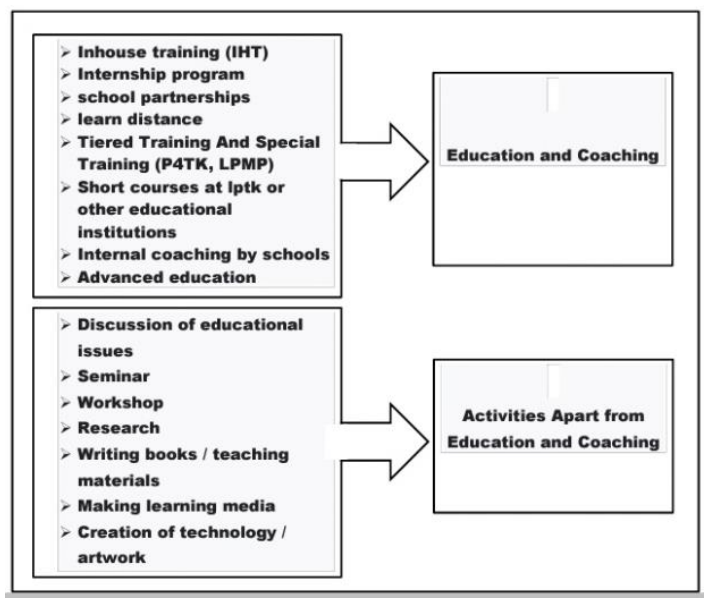

Figure 1.Categories of forms in improving Teacher Competence Source: (Kementerian Pendidikan dan Kebudayaan, 2012)

Another opinion expressed by (Dhuhary, 2012) explains that the ability and skills of teachers are closely related to efforts to improve the ability of the teaching process, and the results achieved by students are divided into four abilities, namely:

Physical education teachers must plan a lesson as a process that must be done optimally so that a plan's objectives are successful. The purpose of planning is a part that contributes to all incidents of learning activities, so good teaching planning will also be good for the expected goals. The planning includes the teacher analyzing learning materials, making semester programs, annual programs, making learning plan implementation units. The existence of this plan will help the readiness of teachers to improve the teaching and learning process.

Physical education teachers gradually carry out the process of implementing learning in a physical education learning teacher with their respective stages where the teacher acts as a teacher, motivator, friend, educator with the teacher's competencies.

Students respond to knowledge from the teacher through experiences that occur in the learning process. The ability that grows in students is the result of the teacher's role in animating the learning atmosphere and student activities that have been arranged in planning. With this, the teacher is able to consider and assess whether the system and methods are correct or if there is repetition if the learning objectives have not been achieved.

Physical education teachers evaluate learning; each learning ends with an evaluation process. This process is carried out in order to see how far the program has been successful. Another benefit of this evaluation process is to monitor the extent to which learners have achieved in learning. According to (Winarno, 2014) evaluation is a process that has been made in a patterned, structured, and systematic way to prove and determine the value determined by the distribution of data during the measurement process.

Physical education teachers must master teaching materials; these materials are adjusted to the conditions of the class and mapped what factors will support learning activities. Teaching tools and materials controlled by the teacher makes it easy to provide structured and detailed knowledge and make it easier to evaluate student scores. Mastery of this teaching material is a form of elaboration of a physical education teacher's teaching hours, namely $2 \times 45$ minutes each face to face; therefore, physical education 
teachers are truly effective and efficient in the learning process.

In a competence development process of training teachers who form or training is held for a mentor, instructor and teacher should be structured and follow the steps below:

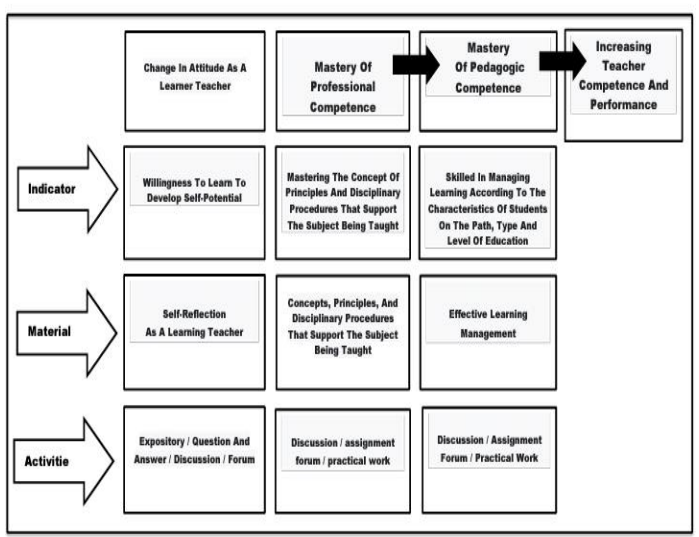

Figure 2. Step Teachers Learning Competency Enhancement. Source:

(Kementerian Pendidikan dan Kebudayaan, 2016)

Relation to a continuous competency development process, the following are types of competency development that can be carried out by schools independently. These programs were adopted from (Kementerian Pendidikan dan Kebudayaan, 2012) Among others, as follows. Competency development is enhanced by the teacher himself (1) The teacher can analyze and provide feedback to students; (2) map back the results of the students' work; (3) provide solutions and responses to students in the learning process; (4) fostering a literacy culture following their scholarship; (5) participate in activities that increase competence.

(Kementerian

Pendidikan

Nasional, 2007) Competency development is carried out in groups with teachers of the same profession, (1) assessing the performance of other teachers; (2) collaboration with peer teachers to assess teacher performance during the learning process; (3) collaborating with teachers prophetic to teach together; (4) discuss with professional teachers and peers to discuss problems faced by schools; (5) writing articles with other teachers; (6) collaborating with the making of learning administration with other teachers. Competency development organized by the school, such as (1) specialized training for all school members; (2) Comparative study with other schools; (3) bring in resource persons or experts from other schools.

4). Direct guidance by the principal of the school

The principal provides guidance, direction, socialization, and supervision of the development of competency teachers in education on an ongoing basis. As for related to developing the competence of physical education teachers at SD Muhammadiyah Nitikan. Physical education teachers must follow the competency standards applicable in Indonesia because they are essential in organizing learning for students. So the success to be achieved must be guided by and refer to the Indonesian National Education Standards or often referred to as the National Education Standards Agency (BSNP). (Mardapi, 2012): explains, "professional teachers must master teaching materials, be ready with learning administration and the character of students." Whereas in Law number 19 of 2005 on National Education Standards article 28 it is explained that: (1) Educating 
agents in sports science must be physically and mentally healthy and have academic quality so that they will have the ability to achieve national education; (2) in paragraph (1) it is stated that an educator must have academic qualifications as evidenced by a diploma or certificate of expertise that is valid in Indonesia. (3) educators have the ability of four teacher competencies that apply at all levels of school level, including (a) pedagogical competence, (b) personality competence, (c) professional competence, and (d) social competence; (4) For someone who has the expertise and is worthy of being an educator, he must pass the feasibility and equivalence competency test: (5) The competence and academic qualifications of an educator is a learning agent as developed by BSNP and stipulated by ministerial regulations.

The improvement and development carried out by teachers is useful and can produce good quality education and create an educated generation. Several ways that school principals can do to help develop better physical education teacher competencies, namely:

1) Improving Teacher Competence The quality of schools, the quality of education, and the excellent and superior achievements of students are, of course, strongly influenced by the professional quality of their teachers. The components that must be improved and enhanced by a teacher to improve these four competencies include: (1) teachers need to expand innovative teaching methods and strategies, (2) teachers are more skilled in class management, (3) conduct small exams or research in class (4) teachers can motivate students to achieve, (5) improve discipline and do not delay work, (6) maintain and improve academics and science, (7) good at managing time. With such conditions, of course, the teaching staff's quality will continue to increase and develop.

Apart from the importance of four main competencies that must be possessed by educators, namely pedagogy, personality, social, professional, educators must also renew their knowledge and must improve their academic quality, which is continuously honed in a gradual, ongoing, ongoing manner according to scientific developments, sophisticated technological changes, and the art of innovation in learning. In the future, teachers are required to have abilities in the field of technology in the $21 \mathrm{st}$ century so that teachers can provide knowledge for students according to the times and have the ability to think critically, creatively, communicate skills and be able to work with others.

2) Knowledge and scientific development

The principal facilitates physical education teachers to further improve their professionalism, such as following training, referee training, trainer training, or innovation competitions organized by accredited and authorized bodies in improving teacher professionalism.

Education teachers are also asked to study and study the K13 curriculum for physical education at the primary school level, both the main curriculum and the other curriculum where these physical education subjects and 
materials for grades 1,2 and 3 are still incorporated in the literary content, while the subjects and material for class physical education 4,5 and 6 apart.

Physical education teachers are required to participate in teacher forums to hone their profession and personality by taking an active role in organizations such as; PGRI, the Teacher Working Group (KKG), and other working groups.

3) Providing supervision

The principal must master the technique of assessing and have spiritual leadership to be able to find out about school achievements in the field of sports. Supervision carried out by the principal is not to find mistakes and shortcomings but to provide input, advice, and guidance for physical education teachers. The principal must have qualifications, managerial knowledge, and broad insight so that it will be easy to provide solutions to school problems and learning problems, establish communication with physical education teachers and other teachers, control, monitor the development of physical education competencies.

Physical Education, Sports, and Health, which is often abbreviated as PJOK, is the process of physical education is the only learning to use a variety of physical skill activities to be able to produce physical changes including; physically, mentally, and emotionally (Setyawan, 2016). PJOK is a subject integrated with the education unit as a whole; PJOK subjects aim to improve physical abilities, improve physical fitness, train movement skills, think innovatively, act in fireplay, have a leadership spirit, live in a healthy environment. (Surahni, 2017) explains that physical education is science contained in PJOK subjects. So the subject of PJOK itself is a science to improve the physical quality of the physical, emotional, and mental skills of students. In the PJOK subject, each student collaborates between body and soul as part of the whole money and influences each other. These students' eyes have a broad scope of knowledge on improving human movement.

As a professional teacher, besides having four competency qualifications, they are (1) pedagogical competence, (2) personal competence, (3) social competence, (4) professional competence as stipulated in (Kementerian Pendidikan Nasional Undang-Undang Nomor 14 Tahun 2005 tentang Guru dan Dosen, n.d.) article 10 paragraph 1 . In article 20 , an educator also should improve his competence on an ongoing basis. Then educators can update, develop, improve their knowledge, increase knowledge, skills, and carry out tasks thoroughly professional.

\section{CONCLUSION}

This study concluded that the principal made full efforts to develop physical education teachers at Muhammadiyah Nitikan Yogyakarta Elementary School to be able to teach physical education well and master learning materials. physical education teacher in elementary schools must have good teaching skills, a spiritual mentor, be 
able to direct, be able to train, be thorough in assessing, understand the teaching material and be able to evaluate students in the field of Physical Education. As for the program carried out by the right school principal to improve the competence of Physical Education teachers by; 1) planning for developing the competence of PJOK teachers by following the Teacher Working Group (KKG) and the Subject Teacher Conference (MGMP); 2) Mapping the competence of teacher skills through competency tests and writing scientific articles or classroom action research (PTK); 3) Providing opportunities for PJOK teachers to take part in sports training and seminars; 4) Direct coaching by the principal.

But on the other hand, there are still weaknesses in the use of learning styles, learning methods, and information technology in physical education learning. The program is expected to develop the competence of physical education teachers who are deemed inadequate and need to be improved through these activities.

\section{REFERENCES}

Bukit, B. dkk. (2017). Pengembangan Sumber Daya Manusia Teori, dimensi Pengukuran, dan Implementasi dalam Organisasi. Yogyakarta: Zahir Publishing.

Dhuhary, A. A. (2012). Peningkatan Kompetensi Guru Pendidikan Jasmani Olahraga Dan Kesehatan. Pendidikan Olahraga Pascasarjana UM, (1), 294306.

Kementerian Pendidikan dan Kebudayaan. (2012). Kebijakan Pengembangan Profesi Guru. (Https://Www.Usd.Ac.Id/f

Fakultas/Pend Pendidikan/F113/PLPG2015/Modul/03
$\% 20$ Policy\% 20profesi_Modul\% 20Guru\% 20Kelas\% 20SD-4.Pdf), Accessed 23 April 2017.

Kementerian Pendidikan dan Kebudayaan. (2016). Panduan untuk Program Peningkatan Kompetensi dalam Mode Gabungan Tatap Muka, Online, dan Online. Online), (Https://Docs.Google.Com/Viewer?A= v\&pid=sites\&srcid $=Z G V m Y X V s d G R$ VbWFpbnxhenNpcGdwb2.

Mardapi. (2012). Pengukuran Penilaian \& Evaluasi Pendidikan. Yogyakarta: Nuha Medika.

Mardhatillah, M. \& K. (2019). Musdiani \& Khausar, Khausar. (2019). Analysis the role of headmaster in applying quality of education in primary school kabupaten, Aceh Barat.

Musdiani \& Khausar, Khausar. (2019). Analysis the Role of Headmaster in Applying Quality of Education in Primary School Kabupaten, Aceh Barat, (10.33258/birle.v2i3.349), 19-27.

Muhajir. (2016b). Buku Guru Pendidikan Jasmani, Olahraga, dan Kesehatan. Pusat Kurikulum dan Perbukuan, Balitbang, Kemdikbud.

Mulyana. (2013). Standar kompetensi dan sertifikasi guru. Bandung: PT.Remaja Rosdakarya.

Rosyada, dede. (2013). Creative Thingking. UIN Syarif Hidayatullah Jakarta, edisi3.

S., Bustan, Herculanus Bahari Sindju, M., \& Suib. (2019). Tugas Kepala Sekolah Sebagai Pendidik Dan Pemimpin Di Sekolah Dasar. Portal Jurnal Ilmiah Universitas Tanjungpura.

Selvi, K. (2011). Teachers' Competencies. Cultura. International Journal of Philosophy of Culture and Axiology., 7. 167-175.

Setyawan. (2016). Peningkatan mutu pendidikan jasmani melalui pemberdayaan teknologi pendidikan. 110-139. Jakarta Timur: Seminar Nasiolnal Olahraga 2016 Program S3 Pendidikan Olahraga Pascasarjana $\mathrm{UNJ}$,

Sugiyono. (2019). Metode Penelitian Pendidikan Pendekatan Kuantitatif, Kualitatif, dan R@D. Bandung: Afabeta. 
Surahni. (2017). Pendidikan Jasmani, Olahraga dan Kesehatan (PJOK) sebagai Sarana Pendidikan Moral. The 6th University Research Colloquium 2017, 41-46.

Undang-Undang Republik Indonesia nomor 23 Tahun 2014. (2014).

Wardoyo, Cipto\&Herdiani, A. (2017). No Title. Teacher Professionalism: Analysis of Professionalism Phases. International Education Studies, 10. 90. 10.

Winarno. (2014). Evaluasi Hasil Belajar Pendidikan Jasmani Olahraga dan Kesehatan. . Malang: Universitas Negeri Malang. 